\title{
HIZBUT TAHRIR MALAYSIA: the Emergence of a New Transnational Islamist Movement in Malaysia
}

\section{Mohamed Nawab Mohamed Osman}

Associate Research Fellow at the S. Rajaratnam School of International

Studies and a Ph.D Candidate at the Department of Political and Social

Change, Australian National University

\section{Abstract}

This paper looks at the Hirbut Tabrir of Malaysia and places it in the context of the wider and deeper development of Muslim politics and mass mobilisation across Asia and the world at large. While much has been written about the Hirbut Tabrir of Indonesia (HTI), little is known about the HTM. This paper traces the initial arrival of the HT to Malaysia, via the network of Malaysian students and activists who were educated abroad and who have managed to build their own inter-personal networks and relationships outside the parameters of mainstream political Islam and the state apparatus in the country. Furthermore it is interesting to note that HTM in Malaysia takes its own unique stand on Islamic issues with relation to the mainstream Islamic party PAS and the MalayMuslim UMNO party. The paper therefore attempts to locate the ideological positioning of the HTM in the wider context of Islamist politics in contemporary Malaysia and to analyse its relationship to the wider currents of ethno-communal as well as religious politics in the country as a whole.

Keywords: Hizbut Tahrir Malaysia, transnational movement, activists' network, PAS, UMNO 


\section{A. Introduction}

Transnationalism is not a new phenomenon within the Islamic religion. Islam has always maintained a transnational dimension. Various rituals such as the annual pilgrimage to the holy city of Makkah exemplify this. The medieval Caliphates within the Muslim World is transnational and stretched from Europe to India. Early Sufis and Muslim traders have always maintained a transnational network that spanned the continents of Africa, Europe and Asia.

Yet, transnational Islam is today viewed with trepidation. This has to do with the fact that many terrorist groups such as the Al-Qaeda framed their ideology around the idea of transnational Islam and the revival of the medieval Islamic Caliphate. Yet, Al-Qaeda is new compared to another group that has placed the revival of the Islamic Caliphate as its political aim since 1953. This group is the HizbutTahrir-al-Islami (HT). While Al-Qaeda used violence to achieve its end goal of the Caliphate, HT has focused its activities towards developing a core group of cadres who will be responsible for the reestablishment of the Islamic Caliphate.

Today, HT has developed a massive network of members and have chapters in forty-five countries spanning five continents. In the Southeast Asian region, HT has focused its attention on developing strong chapters in Indonesia and Malaysia. While HT remain a marginal group, its growth in Malaysia has become worrisome for many within the Malaysian political system. Members of the main ruling party, the United Malay National Organization (UMNO) and the Islamic Party of Malaysia (PAS) perceive HT as a threat to their political base. ${ }^{1}$

In light of such opinions, it is the aim of this paper to analyze the emergence of Hizbut Tahrir Malaysia (HTM) as a political force in the country. While HTM is today a small organization, the paper argues that it is likely to emerge as a third alternative within the Malaysian political system as the main Malay-Islamic parties, UMNO and PAS reshape their respective Islamic agendas. The paper will be divided into three parts. The first part will discuss the emergence of HTM, its aims and objectives. The second part of the paper will examine the

${ }^{1}$ Conversation with a member of UMNO in June 2007. 
political strategies of HTM. The last part will analyze the potential of HTM to emerge as a third Islamist alternative within Malaysian political system. $^{2}$

\section{The Origins of Hizb ut-Tabrir}

HTM is a chapter of the larger HT organization. Palestinian Islamic scholar, Taqiduddin An-Nabhani, founded the organization in 1953. An-Nabhani came from a prestigious family of eminent scholar. His grandfather, Yusuf An-Nabhani was a religious official of the Ottoman Caliphate. As such, he received his early education at various prestigious Islamic institutions including the Al-Azhar University. Upon completion of his studies, An-Nabhani worked as a religious teacher. Later he worked for the Shariah court in Haifa rising to the position of Judge of Al-Ramla Court until the year 1948 when the Arab-Israeli war broke out. The experience of the Arab-Israeli conflict affected An-Nabhani tremendously. An-Nabhani felt that the loss the Arabs encountered during the 1948 war was attributed to their failure to follow the teachings of Islam. He began developing a new approach to the understanding of Islam, which fused modernist Islamic political ideology, and traditional Islamic teachings. To implement the ideas he had envisaged, An-Nabhani formed HT. For An-Nabhani, HT is a political party, which is working towards the revival of the medieval Islamic Caliphate.

HT emerged largely due to the experience of the Arab-Israeli conflict. However An-Nabhani felt that the party needed to expand to other parts of the Arab World. By the time of his death in 1977, HT had established chapters in virtually all Middle Eastern and North African countries. HT expanded further under the leadership of Sheikh Abdul Qaleem Zalloum, its second leader. Interestingly, this expansion occurred by chance. HT was seen as threat by Arab countries after it initiated several coup attempts in Egypt and Jordan. Its members were

2 The author has utilized interviews and personal communications with members of the HTM between 2005 and 2007 for the purposes of this paper. He also attended several seminars and forums conducted by the TM in Kuala Lumpur, Melaka and Johor Bahru. Due to the secretive nature of the party in Malaysia, the author will keep the names of some of the HTM members anonymous. 
prosecuted and were forced to flee to Western countries including the United Kingdom, Germany, Australia and United. ${ }^{3}$

Paradoxically, HT's growth and expansion into other Muslim countries occurred through the West. Armed with European passports that allowed them to travel freely, HT members began traveling to Muslim countries to spread its ideology. ${ }^{4}$ This began first with Central Asian countries following the collapse of the Soviet Union and subsequently to South and Southeast Asian countries. ${ }^{5}$ Under the leadership of its third leader, Sheikh Ata Abu Rashta, HT expanded significantly and built important bases in South and Southeast Asian countries. ${ }^{6}$

\section{Hizb-ut-Tabrir: Objectives and Methodology}

HT claims to defer to Prophet Muhammad's method of setting up the state of Madinah, which An-Nabhani described as the first Islamic state. This supposed method of achieving power involved three stages. In the first stage, known as the stage of culturing, HT aims to produce people who believe in the idea and the method of the Party. This group will form the core group of leaders who would be responsible for the revival of the Caliphate.

At the second stage, known as the stage of interaction with the Muslim community, the party seeks to educate Muslims about the importance of the Caliphate and the need to revive this Islamic institution. At the third stage known as the stage of the ruling, the party works towards establishing a government, which will implement Islam comprehensively. ${ }^{7}$ To achieve this final stage, the core group

${ }^{3}$ Interview with Burhan Haniff, member of Hizb ut-Tahrir Britain, June 2007.

${ }^{4}$ The movement activities in Central Asia were captured in Zeyno Baran, Hiøb ut-Tahrir: Islam's Political Insurgency (Washington: Nixon Center Monograph. December 2004) and Ahmed Rashid, Jihad: The rise of Militant Islam in Central Asia (New Haven: Yale University Press, 2002), pp. 115-137.

${ }^{5}$ Interview with Maajid Nawaz, former member of Hizb ut-Tahrir Britain, Oct 2007.

${ }^{6}$ Sheikh Ata Abu Rashta, the former spokesman for HT in Jordan took over the helm of its leadership in 1995.

${ }^{7}$ Hizb ut-Tahrir Britain, The Method to Re-Establish the Khilafah and Resume the Islamic Way of Life (London: Al-Khilafah Publications, 2000), pp. 88-110. 
will seek nusrah (political assistance) from important members of the society such as politicians, military leaders and civil society leaders.

A HT member drew parallel between this stage of HT's Islamic Revolution to that of Mikhail Gorbachev's decision to disband communism. He noted that Gorbachev had been a communist but yet his decision and that of key Soviet leaders to change the country's political system led to the collapse of communism and triumph of capitalism. He noted that a similar development would occur in the Muslim World leading to the formation of this Islamic Caliphate. ${ }^{8} \mathrm{HT}$ opens its membership to all Muslims regardless of race, Islamic sects and gender. As such, HT claims to have members who subscribed to Shiite Islam in Iraq and Lebanon. This differentiates HT markedly from many other Islamist organizations such as the Muslim Brotherhood who often view the Shiite beliefs negatively. Another interesting feature of its membership is the fact that women were encouraged to be members and held equal rights to men within the party. Although, women's activities were often held separately, woman often sit in HT's leadership hierarchy.

\section{B. History of the Hizbut Tahrir in Malaysia}

Hizbut Tahrir Malaysia began as a student-based movement, recruiting mainly among the student community of Malaysia. Many of these students had been recruited while studying in universities such as Imperial College, University of Sheffield and School of Oriental and African Studies (SOAS) in the early 1990s. ${ }^{9}$ These initial members of HTM were seen to be insufficiently equipped by HT's leadership in the Middle East to start a strong and sustainable chapter of the party in Malaysia. To assist the HTM leaders, HT's main leadership instructed a member of Hizbut Tahrir Indonesia (HTI) to move to Malaysia for the purpose of preparing HTM members for their future role as leaders of HTM in Malaysia. This member of HTI, Hafidz Abdurrahman is now the chairman of Hizbut Tahrir Indonesia.

${ }^{8}$ Interview with Fahmi Amhar, Member of HTI Central Committee, April 2009, Jakarta.

9 Personal Communications with Hizb ut-Tahrir Malaysia members 
During its formative years, HTM utilized several front organizations, including the Muslim Intellectual Network of the Malay World (IKIN) to organize its activities. IKIN was formed in 1997 after a large pool of HTM activists returned back to Malaysia from the UK. Prior to this, there were pockets of HT members operating all around Malaysia. However, they were not organized under a structured leadership. At this point, the HT central leadership also placed Indonesia, Malaysia and Singapore within the same wilayab. ${ }^{10}$ The HTM leadership reported directly to the Mu'tamad (Representative of the Amir of HT) in Indonesia, Muhammad al-Khaththath at this point of time. As highlighted earlier, members of HTM refrained from using the name Hizbut Tahrir Malaysia. This was to avoid prosecution from the Malaysian government that viewed transnational groups like HT with suspicion. The tense political climate following the sacking of former Deputy Prime Minister of Malaysia, Anwar Ibrahim also meant that political groups that are seen as a potential threat are likely to be prosecuted.

During this formative year, HTM members underwent an intense period of studying HT's key texts such as the Systems of Islam, The Political System of Islam and The Economic System of Islam. These study sessions were led by Hafidz Abdurrahman. At the same, time, HTM leaders were building smaller chapters of HTM in different parts of the country. They also assisted members of HT in Singapore to build a chapter of the party. ${ }^{11}$

By 2004, HTM leaders felt sufficiently confident to elevate the party to its next stage. HTM leaders began using the name Hizbut Tahrir Malaysia more openly. ${ }^{12}$ HTM began to print its name in various publications that it produced such as the Sautun Nahdah leaflet. They also began to openly distribute these leaflets at mosques during the weekly Friday prayers in Kuala Lumpur, Ipoh, Kota Bahru and Johore

\footnotetext{
${ }^{10}$ Interview with Muhammad al-Khaththath, HTI Leader, August 2007, Jakarta.

${ }^{11}$ For a detailed description of HT in Singapore, see Mohamed Nawab Mohamed Osman, "Reviving the Caliphate in Malaysia", Studies in Conflict and Terrorism (June 2009, forthcoming).

${ }^{12}$ Interview with Hafidz Abdurrahman, Chairman of HTI, August 2007, Jakarta.
} 
Bahru. They also began to organize seminars and mass demonstrations to expand its network throughout Malaysia. In 2006, HTM officially sent in an application to the Malaysian authority to be registered as a political organization.

In August 2007, HTM's leader, Hakim Osman identified himself openly as the President of HTM and the public face of HTM. Interestingly, this is a departure from the usual practice of HT in other countries where HT is often represented by a spokesperson. However, this is part of its strategy to conform to the Malaysian norm of having the position of President in Muslim organizations.

\section{Leadership and Membership Composition}

The official leader of HTM today is Hakim Osman. Hakim had been a successful lawyer for several years. His esteemed clientele included prominent Malaysian singer, Siti Nurhaliza. Hakim Osman gave up his law practice to work full time for HTM. HTM's membership also boost many successful academics including Dr. Sharifuddin Md Zain, the Head of Department at the University of Malaya's Chemistry Department, Dr Salehuddin Ibrahim, an Associate Professor at the Electrical Engineering Department in Malaysian Technological University and Dr Agus Arsad, lecturer at the Polymeric Engineering Department in the same university. These academics graduate from prominent UK universities such as the Imperial College and University of Sheffield.

There are also economists, doctors and dentists who are members of the group. While many of its members are highly educated and hail from middle and upper-middle income backgrounds, there are several members who are lay persons doing odd jobs such as lorry drivers and mechanics. Outside the professional group, its key members are tertiary students. These students are generally recruited from local universities such as UM, UTM and the National University of Malaysia (UKM). Prior to 2004, a Malaysian member of HT in the United Kingdom was also assisting HTM in its recruitment process. This particular member was married to a British citizen and had played a major role in recruiting Malaysian tertiary students studying in the UK. In general, the HTM members are from the highly educated group. 
The leadership structure of HTM is similar to that of the larger HT. HT divides the Muslim World into different provinces known as wilayah. ${ }^{13}$ In the minds of HT leaders, these wilayabs represent provinces of their future Caliphate. ${ }^{14}$ At the apex of its leadership is the amir (leader) of Hizbut Tahrir. A committee made up of its top leaders assists the Amir. Little is known about this leadership and where they are based. Some ex-members of the group speculated that these leaders are either in Jordan or West Bank. The second layers of leaders are members of the wilayah committee. A mu'tamad who reports directly to the amir heads this committee. Communication between the amir and mu'tamad occurs via emails that are encrypted. The amir also sends envoys to visit a particular wilayah to monitor its developments and resolved problems that may be occurring in the wilayah. In the case of HTM, the official leader of HTM is Hakim Osman. Yet, Hakim Osman is likely to be the public face of HTM and the real leader of HTM might only be known amongst members in the wilayah committee. The third level of its leadership structure is the local area committee. A naqib leads this local committee. A local area committee also assists the naqib. The naqib is in-charge of halaqabs conducted in the locality. Each member of the local committee (mushrif) leads halaqabs comprising five to eight daris (students).

For most of its history, Malaysia was placed in the same wilayah as Indonesia and Singapore. This means that the head of the Malaysian chapter was seen as the naqib and reported to the mu'tamad in Indonesia. In 2001, the Malaysian chapter was accorded the status of wilayah. ${ }^{15}$ As HTM began to expand, naqibs were appointed at the state level. ${ }^{16}$ By 2008, HTM has appointed naqibs in all of the Malaysian states except for the states of Sabah and Sarawak. Similar to HT in other parts of the world, HTM is growing in the important urban centers of Malaysia such as Kuala Lumpur, Melaka and Johor Bahru.

\footnotetext{
${ }^{13}$ Mohamed Nawab, "Reviving the Caliphate".

${ }^{14}$ For more on the leadership structure of HT, see Taji-Farouki, Fundamental Quest, p. 116

${ }^{15}$ Interview with Muhammad Al-Khathath, August 2007, Jakarta,

${ }^{16}$ Mohamed Nawab, "Reviving the Caliphate".
} 
The process of attaining membership in HTM is indeed an arduous one. Potential members are first identified through mass activities organized by the party such as public lectures and seminars. Those identified and deemed to be potential recruits are invited to attend a weekly study circles called halaqah. Each halaqab is led and managed by a HTM member known as the mushrif. The mushrif will monitor the advancement of members in his study circle. Members are gauged based on regular attendance, their religiosity (based on their observance of the five rituals of Islam) and their leadership abilities. ${ }^{17}$ For HTM, halaqah are forums for discussions of ideas related to the concepts advocated by Hizbut Tahrir. Daris in these halaqah are also required to master four key aspects of HTM's philosophy; Islam as an Ideology, Islam as a Political Idea, Hizbut Tahrir as an Islamic political organization and Islamic proselytizing process. It is only after the mushrif of a halaqah is convinced that a daris is completely ready that he is invited to attend a more structured halaqab known as the Halaqab Murakkazah. By this stage, these daris are considered to be sympathizers (official daris) of the party. To inculcate an understanding of Hizbut Tahrir, the new mushrif will expose his daris to several important books written by HT's ideologues such as the Political System of Islam, Systems of Islam (Nizm al-Isläm), Islamic Order and the Ideas of Hizbut-Tahrir (Mafabim Hizb-ut-Tabrir). Daris are also asked to assist HTM leaders in organizing activities such as seminars, talks and encouraged to attend demonstrations.

It is through their enthusiasm and commitment in these activities coupled with their internalization of HTM's concepts that a daris is then invited to be a full member. Often this process may take up till four years. Often, many daris will remain sympathizers and will never elevate to the position of full members. From here, one can deduced that HTM is in fact an 'elitist' organization. Elitist here does not mean that HTM recruits only from the highly educated group alone. However, only a small group of chosen persons will lead the party in attaining its goal of establishing the Caliphate. This is similar to the concept adopted

\footnotetext{
${ }^{17}$ Interview with Dr. Sharifuddin, August 2006, Kuala Lumpur.
} 
by the Jamaat-e-Islami party in Pakistan when Pakistani thinker and scholar Maulana Abul A'la Maududi led it. ${ }^{18}$

\section{Attraction to HTM}

As mentioned earlier, HTM is today growing in Malaysia. While its size is minuscule compared to the larger Muslim organizations and political groups, HTM has emerged as an important Muslim group. Hafidz Abdurrahman noted that the growth of HT in Malaysia is faster than its growth in Indonesia. He noted that by the time he left Malaysia in 2004, HTM was already established in virtually all of the Malaysian states. In addition, HTM has also received public attention because of several actions it has taken in the past. This is indeed a remarkable feat for a group that has only emerged publicly in 2005. Most importantly, HTM is gaining more support from young highly educated Malaysian Muslim. This is especially puzzling given that HTM's aim of reviving the Caliphate might be seen as romantic and irrational by some. There are several factors that can explain the attraction to HTM. a. Muslim Youth Identity Crisis

Like young Muslims in many countries, young Malaysia Muslims are undergoing an identity crisis. Many Muslim youths have different expectations from their society as compared to their parents. Many of these youths have different cultural reference points, different life at school or university and consume different styles of entertainment. Unlike their parents, they are more likely to eat in one of the American fast food outlets, watch MTV and wear clothes inspired by the latest fashion in Hollywood.

The growing consumerism in Malaysia have led to social problems such as drugs, over-drinking and unhealthy sexual behavior. The official religious position represented by government sponsored institution and by the opposition Islamic Party of Malaysia (PAS) tend to focus on the need for Muslim youths to reject Western culture. The tagline of the Islamic alternative view is that Muslim youths must adopt their IslamicMalay identity and reject the evils of Western culture. This approach

\footnotetext{
${ }^{18}$ See Sayyid Reza Vali Nasr, The Vanguard of the Islamic Revolution: The Jamaat-iIslami of Pakistan (Berkeley: University of California Press, 1994), pp. 28-47.
} 
to religion is often top-down and fails to relate to the experience of these Muslim youths. Muslim parents in Malaysia often support these views. As a result of the onslaught of Western consumer/popular culture and the less than appealing Islamic alternative, Muslim youths are often left confused about their identity. As a result, they either reject the Islamic alternative and adopt what they deem as a Western identity or adopt a new Islamist position. These youths often turn to pro-Islamic groups such as PAS, the Malaysian Assembly of Muslim Youths (ABIM) and HTM.

At the same time, many of those in the former group can turn to become Islamists after they attain a certain age as they see a need to 'repent' from their 'sins'. Such a process can be understood by the experiences of many HTM members. One HTM member noted that he was leading a jahil (ignorant and un-Islamic) lifestyle often frequenting pubs, drinking and womanizing. It was after he was left by a woman that he was in love with that he decided to repent and was assisted in doing so by a member of HTM. ${ }^{19}$ The question that should then be posed is why young members of HTM choose HTM rather than the myriad of other Islamic/Islamist groups and organizations working in the country. This is probably best understood by developments occurring within other Islamic groups.

b. Perceived Compromise of PAS and Other Islamist Groups

Historically, the landscape of Islamic groups in Malaysia has remained the same. Many of these groups are either aligned to PAS or the United Malay National Organization (UMNO) ${ }^{20}$ In the 1980 s and 1990s, PAS represented groups espousing for the formation of an Islamic State while UMNO strived to form a 'moderate Islamic state'. By the late 1990s, this trend seems to have change with UMNO leaders increasingly using Islam as a political tool to out-Islamise and outmaneuver PAS in the political battle between the two. However, the formation of the People's Coalition (Pakatan Rakyat, PR) after the 2008 elections comprising of PAS, the People's Justice Party (Parti

${ }^{19}$ Interview with a Member of HTM. His name will not be revealed due to the nature of his current position as a HTM leader.

${ }^{20}$ There are exceptions to this such as the Muslim Professional Forum, which is a neutral NGO. 
Keadilan Rakyat, PKR) and the Democratic Action Party (DAP) have resulted in a new development in PAS. PAS was forced to moderate their position on the Islamic state issue given the success of the PAS in the 2008 election. This has led to a discernible moderation of the party's Islamist commitment. They were forced to focus on the more egalitarian aspects of Islam such as social justice, protecting human rights and establishing a corruption-free political system. This allowed the party to work more effectively with its political partners in the PR to establish a strong alternative to the current government led by UMNO.

The moderation of PAS has come at a cost. Many of its more puritan members are disappointed at the perceived decision of its leaders to sacrifice the Islamist agendas at the expense of power. Many of the Islamist NGOs are also supportive of PAS' moderate stance. In discussions between leaders of the Jemaah Islah Malaysia (JIM) and PAS held in July 2008, JIM had urged PAS to remain in the PR to represent the position of pro-Islamic groups in Malaysia. ${ }^{21}$

The moderation of Islamist groups in Malaysia have led to an influx in support for HTM or at least its position. In articles written by its leaders, HTM has expressed disappointments with the state governments led by PAS for allowing un-Islamic activities to continue in these states such as pig rearing. Some of its members have already left the party to become members of HTM. ${ }^{22}$ One of these members informed that his decision to quit PAS is due to the fact that he was never really comfortable with PAS' support for democracy and felt that the approach that HTM advocate is a more Islamic approach. ${ }^{23}$ HTM is making a significant impact among students in various institutions and have been able to draw it support from former members of Islamic student groups affiliated with PAS. ${ }^{24}$ Muslim youths who are not affiliated to any Islamist group felt that HTM is more sincere in

\footnotetext{
${ }^{21}$ Interview with Zaid Kamaruddin, President of JIM, August 2008, Jakarta.

${ }^{22}$ Conversation with former PAS Deputy President, Ustaz Hassan Shukri and former PAS Youth chief, Ustaz Abu Bakar Chik, Mar 2008.

${ }^{23}$ Conversation of HTM member who was a former PAS member.

${ }^{24}$ Interview with former PAS Deputy President, Ustaz Hassan Shukri.
} 
its efforts to revive Islam in the country. One of this youth argued that PAS is just seeking to win elections while HTM has no such ambition. ${ }^{25}$ He explained that the methodology espoused by HTM is one that cannot corrupt an individual, as he or she will have nothing to gain unlike a member of PAS or UMNO who could be offered government positions which comes with money and perks. ${ }^{26}$ For many young members of HTM, the political independence of HTM is one of its key attractions.

c. Mobilization Strategies

Disappointment with other Islamic organizations is not the only factor that is attracting members to HTM. HTM has been able to traditional successfully employ various recruitment strategies to its advantage. HTM utilized methods of recruitment such as producing various publications. The most important of these publications is Sautun Nabdah. This is a weekly pamphlet that the group produces and distributes at mosques throughout the country after the obligatory Friday prayers. HTM also promotes the sale of key texts of the group. These books are often translated in Indonesia and brought to Malaysia by members of Hizbut Tahrir Indonesia residing in Malaysia. HTM also utilizes its website, www.mykhilafah.com to attract interest in the group. The website features a daily reporting of various domestic and international news related to the Muslim World. These articles are often followed by commentaries about the articles from members of HTM. ${ }^{27}$

HTM members have utilized the internet effectively for recruitment purposes. HTM members are active bloggers. ${ }^{28}$ They are also active contributors in online forums that are popular with young Malaysian Muslims such as Ummah Online Forum and Melayu.com. ${ }^{29}$ In addition, several HTM members are also beginning to utilize the increasingly popular networking site, Face Book, to encourage their

${ }^{25}$ Interview with Hafiz Mujahid, December 2007, Kuala Lumpur.

${ }^{26} \mathrm{Ibid}$.

${ }^{27}$ Mohamed Nawab, "Reviving the Caliphate".

${ }^{28}$ See http://hafizmujahid.multiply.com. Accessed on 2 May 2009.

${ }^{29}$ For examples of these postings, see http://www.geocities.com/ ummahonline/suratpembaca/suratpembaca05.htm and http://www.melayu.com/ v2/sembang2/mesej.php?thread=15184, Accessed on 30 December 2007. 
friends to attend HTM functions. Some of HTM members are also part of various groups which form part of the Face Book Online groups such as the Hizb ut-Tahrir group, the Revival of the Khilafah group and the International Khilafah Conference 2007 group. ${ }^{30}$

Public demonstrations are another tool used by HTM in recruiting new members. While other Islamic and political groups in Malaysia commonly use demonstrations, the nature of HTM's demonstrations is unique. At the height of the Gaza conflict in March 2009, Malaysian Islamic groups and other NGOs began holding demonstrations against the Israeli atrocities perpetrated on the Palestinians. Other groups began boycotting American goods for the alleged support the Americans lent to Israel. However, HTM held a demonstration outside the Ministry of Defence in Kuala Lumpur calling for the Malaysian army to dispatch its troops to defend Palestine. This was an unprecedented move, which drew large support for HTM.

d. Ideology

Prior to explaining the attractiveness of its ideology to its adherents, it is perhaps useful to briefly discuss the concept of ideology as formulated by political theorist Michael Freeden. Freeden rejects the traditional definition of ideology which sees it as a static belief system. Rather, Freeden argues, that ideologies must be understood from their respective semantic fields. For Freeden, ideology consists of concepts that will evolve and change over time. Each ideology may be seen as having both core and secondary concepts. Concepts can become less or more important over time. Similiarly new concepts may emerge to compliment or replace old concepts. By studying the conceptual evolution of ideologies, Freeden observes that the relative "political success" of an ideology depends on its ability to impose the belief that its own conceptual definitions are the "correct ones". The prevalence of a certain concept of ideology is dependent on interideological and intra-ideological contest. Applying Freeden's concept of ideology on the ideology of Islamism, one would note that the core concept in Islamism is its rejection of secularism. All Islamists seek to eliminate secularism from their respective societies. At the same time

\footnotetext{
${ }^{30}$ Personal Observation of Author on the Face Book website.
} 
the secondary concepts within Islamism might differ exemplified by its position on democracy. While the Islamism ideology of HT reject democracy as being un-Islamic, the Islamism ideology of the Muslim Brotherhood accepts democracy as being compatible with Islam. It is in this regard that HTM's Islamism ideology seems to be prevailing against other variants of Islamism in Malaysia. HTM's uncompromising rejection of democracy, capitalism and secularism have strengthened its position significantly. It is seen to the true bearers of Islamism by many who are attracted to the ideology. While HTM take a strong stand against issues such as Muslim conversion to other religions, PAS is forced by political constraints to take a more measured stand on such issues.

It is appropriate at this juncture to bring to the discussion ideas by sociologist, Karl Mannheim about the concept of ideology. For Mannheim, the concept of ideology has two important components, ideology and utopia. Mannheim referred to ideology as total systems of thought held by society's ruling groups to preserve the status quo and hence their political positions. On the other hand, utopia is total systems of thoughts forged by groups opposed to the ruling elites who are interested in the total transformation of society and thus subscribe to system of ideas that direct total change of society. Mannheim argued that

A state of mind is utopian when it is incongruous with the immediate situation and when passed onto actions, tend to shatter the order of things. ${ }^{31}$

In many ways, the views held by HTM are utopian in nature. HT is opposed to the current political and economic system and proposed a complete overhaul of the current world system. Its ideas on the need to revive the Islamic Caliphate is an example of this utopianism. It is here again that HTM's ideology is attractive to many of its adherents. The fact that its ideology is utopian means that it does not need to provide its potential recruits with a real alternative. It simply needs to

${ }^{31}$ Karl Mannheim, Ideology and Utopia: An Introduction to the Sociology of Knowledge (London: Routledge \& K Paul, 1966), p. 341. 
show that there are problems to the current world systems. HTM can simply refer to the Islamic Caliphate and argue that this is the perfect form of governance. At best, they can provide members with abstract ideas about the different systems that will be part of the future Caliphate as can be seen in books such as the Political System of Islam and the Economic System of Islam.

Herein lies another reason why HTM is attracting recruits. Members of HTM often refer to the Islamic Caliphate as the perfect state where everything will run according to Islam. At the same time, they refer to the Caliphate under the famed Caliph Umar Ibn Abdul Aziz where the state was so prosperous that it was difficult to find poor people to give zakat money to. It is vague and obscure yet romantic vision that attract many youth to HTM.

\section{Positioning HTM in Malaysian Politics}

While, it may be too premature to estimate the impact of HTM in Malaysian politics, it is plausible given the current political developments that HTM may grow in number and influence. The backgrounds of HTM's recruit (young and highly educated) points to the possibility that it will continue to be influential in future. For many young Malaysian Muslims, HTM represents a real alternative to PAS and UMNO as the true bearer of Islam in Malaysia. HTM is now being viewed as a serious challenge by PAS and UMNO.

\section{1. $P A S$ and HTM: Intra-Islamist Conflict}

The relationship between PAS and HTM has been marked by volatility over the last few years. PAS had initially maintained a neutral position towards HTM. This is partly due to perceptions within the party that HTM is an insignificant threat to PAS. Members of PAS Youth had even spoken at seminars organized by HTM. One of its members, Mohd Nazry Chik, a PAS Youth leader emphasized similarities between the two groups. He noted that PAS and HTM are working for revival of the Islamic Caliphate. He argued that the minor difference between the two groups is PAS's gradualist approach towards the Caliphate issue while HTM strived for an immediate revival of the 
Islamic Caliphate. ${ }^{32}$ Yet, PAS has become more concerned about HTM. In part, it is due to the fact that HTM has recruited PAS Youth members. ${ }^{33}$

HTM is also making significant inroads into various institutions at the expense of PAS and its affiliated student groups. The threat from HTM was seen to be major enough for the President of PAS, Abdul Hadi Awang to warn PAS members about the threat from HTM. ${ }^{34}$ HTM views PAS as a fellow Islamic group. However, it has not resisted from criticizing its policies in various states that it is in power. For instance, HTM has publicly slammed PAS leaders for exempting nonMuslims from Islamic criminal laws. HTM argued that Islamic laws are created for all mankind and PAS leaders are confused about this issue. ${ }^{35}$ The decision of HTM has also stated clearly that PAS's usage of democracy to revive the Islamic Caliphate is un-Islamic. They have declared elections as being un-Islamic and urged Malaysian Muslims not to vote. ${ }^{36}$

While HTM is not successful in convincing Malaysians to avoid elections at the national level, it's impact at the student elections have led to the lost of PAS affiliated student groups.

\section{HTM and UMNO: My Enemy's Enemy is My Friend}

For the leaders of UMNO, HTM has been an insignificant Islamic group. However, the fact that HTM is a part of a global Islamic party has been a major source of concern for UMNO leaders. Some UMNO members believe that HTM is aided and abetted by foreigners and is doing the biddings of these foreigners to subvert the country.

${ }^{32}$ Seminar Organized by HTM titled America Post Sept 11: Ally or Adversary Date, held on the 11th of Sept 2005.

${ }^{33}$ Conversation with former PAS Deputy President, Ustaz Hassan Shukri and former PAS Youth chief, Ustaz Abu Bakar Chik, Mar 2008.

${ }^{34}$ See Inside Hizbut Tahrir Malaysia, Al-Islam, April 2006. Also see critique of HTM by a PAS member online. http://www.sim.org.my/modules/newbb/ viewtopic.php?topic_id=815\&forum=1\&post_id=5492 Accessed on 9 May 2009.

35 "Hukum Islam DiWajibkan Untuk Semua", Sautun Nahdah, No.156, 11 January 2008.

36 "Pandangan Hizbut Tahrir Mengenai Pilihanraya", Sautun Nabdah, No. 164, 7 February 2008. 
Apparently, HTM is now seen as a threat big enough for the Malaysian government that the Malaysian Special Branch is now watching the group. ${ }^{37}$ In December 2006, a member of HTM was arrested but subsequently released in Temerloh, Pahang for distributing copies of the Sautun Nahdah leaflet.

While HTM is seen to be a potential security threat, the Malaysian government has not attempted to ban the party or clamp down on its members. Many HTM leaders continue to do well in their careers in government linked bodies such as the tertiary institutions. In fact, the Malaysian government seems to be capitalizing on HTM's antidemocratic stance and radical discourse works to its government's advantage. HTM's call for the boycott of elections has seen the weakening of PAS and its affiliate bodies. ${ }^{38}$ The beneficiary of HTM's anti-election stance is UMNO. ${ }^{39}$

On its part, HTM has been highly critical of the Malaysian government and UMNO leaders. HTM members have criticized every single policy of the government in their writings in Sautun Nabdah. In its most recent attack on UMNO, HTM has accused the government of being anti-Islam. ${ }^{40}$ This is due to the fact that the Malaysian court had awarded custody of children to a Hindu lady whose husband had converted to Islam. It is likely that UMNO and the Malaysian government will re-look its policy towards HTM as HTM grows in size and influence.

${ }^{37}$ HTM claims that they are now under surveillance of the Malaysian security outfit. This was stated openly by a HTM speaker at a HTM seminar organized in Kuala Lumpur when he included the Malaysian Special Branch officers in his list of salutation at a Hizbut Tahrir Seminar. See Hizbut Tahrir Seminar on HIJRAH: Titik Mula Islam Sebagai Tamadun Baru Dunia 20 January 2007, Malaysian Islamic College Mosque, Seksyen 16, Petaling Jaya. In his address, Esa Abdullah, a HTM member openly gave his salaam to members of the Malaysian Security Branch even waving his hands at two gentlemen who were filming the whole seminar.

${ }^{38}$ For more on PAS' moderating stance, see Mohamed Nawab Mohamed Osman, "PAS: From Islamism to Post-Islamism", Jakarta Post, 17 Mar 2008.

${ }^{39}$ Culled from a confidential source.

40 “Demi Undi Agama Allah Ditukar Sesuka Hati", Sautun Nahdah, No. 181, 12 May 2009. 


\section{Creating a Third Front for Islamists}

The potential of HTM emerging as a third Islamist is low in the near future. This is due to the fact that PAS and other Islamist organizations remain viable vehicles for many Islamists. However in the long run, this possibility cannot be ruled out. As PAS moves more centre in its political position which is inevitable given the current political developments, HTM is likely to attract more of its members who are hardcore Islamists. At the same time, HTM seems to be building important ties with members of the Malaysian religious bureaucracy. Several of its members are working in the government religious bureaucracy. At the same time, they held meetings with several Muftis in Malaysia. Through some of these interactions, HTM has created a reputation as a true advocate for Islam. One of these Muftis felt that HTM is an Islamic group that is sincerely trying to revive Islam. ${ }^{41}$ The increasing independence of the Malaysian religious bureaucracy and the opposing views (from the Malaysian government) that ulama held over issues related to converting out of Islam is likely to leave a vacuum for HTM to fill. It is unlikely that these ulama will turn to PAS as PAS itself is forced to take a neutral position on these issues due to political considerations. As such, some of these ulama might turn to HTM to champion their position. This will inevitably lead to HTM emerging as a third front for Islamists in Malaysia. Developments in the region such as the success of Hizbut Tahrir Indonesia are also likely to affect the strength of HTM. Ripple effects is likely to be felt in Malaysia if a major development is to occur in Indonesia in relation to HTI.

\footnotetext{
${ }^{41}$ Conversation with Dato' Harrunsani, Mufti of Perak, June 2006, Singapore.
} 


\section{BIBLIOGRAPHY}

Baran, Zeyno, Hiøb ut-Tahrir: Islam's Political Insurgency, Washington: Nixon Center Monograph, December 2004.

"Demi Undi Agama Allah Ditukar Sesuka Hati", Sautun Nabdah, No. 181, 12 May 2009.

Hizb ut-Tahrir Britain, The Method to Re-Establish the Khilafah and Resume the Islamic Way of Life, London: Al-Khilafah Publications, 2000.

http://hafizmujahid.multiply.com. Accessed on 2 May 2009.

http://www.geocities.com/ummahonline/suratpembaca/ suratpembaca05.htm, accessed on 30 December 2007.

http:/ / www.melayu.com/v2/sembang2/ mesej.php?thread=15184, accessed on 30 December 2007.

h t t p : / / w w w.si m.org.my / module s / n e w b b / viewtopic.php?topic_id $=815 \&$ forum $=1 \&$ post_id $=5492$, accessed on 9 May 2009.

"Hukum Islam DiWajibkan Untuk Semua", Sautun Nahdah, No.156, 11 January 2008.

Mannheim, Karl, Ideology and Utopia: An Introduction to the Sociology of Knowledge, London: Routledge \& K Paul, 1966.

Nasr, Sayyid Reza Vali, The Vanguard of the Islamic Revolution: The Jamaati-Islami of Pakistan, Berkeley: University of California Press, 1994.

Osman, Mohamed Nawab Mohamed, "PAS: From Islamism to PostIslamism", Jakarta Post, 17 Mar 2008.

_- "Reviving the Caliphate in Malaysia", Studies in Conflict and Terrorism (June 2009, forthcoming).

"Pandangan Hizbut Tahrir Mengenai Pilihanraya", Sautun Nabdah, No. 164, 7 February 2008.

Rashid, Ahmed, Jihad: The rise of Militant Islam in Central Asia, New Haven: Yale University Pres1s, 2002. 